\title{
Synthesis, Characterization and Crystal Structures of Fluoro-Substituted Aroylhydrazones with Antimicrobial Activity
}

\author{
Fu-Ming Wang, ${ }^{1,}{ }^{*}$ Li-Jie Li, ${ }^{2}$ Guo-Wei Zang, ${ }^{2}$ Tong-Tong Deng ${ }^{2}$ \\ and Zhong-Lu You ${ }^{3}$ \\ ${ }^{1}$ Key Laboratory of Coordination Chemistry and Functional Materials in Universities of Shandong, \\ Department of Chemistry, Dezhou University, Dezhou 253023, P. R. China \\ ${ }^{2}$ School of Chemistry and Chemical Engineering, Beijing Institute of Technology, Beijing 100081, P. R. China \\ ${ }^{3}$ Department of Chemistry and Chemical Engineering, Liaoning Normal University, Dalian 116029, P. R. China \\ *Corresponding author: E-mail: wfm99999@126.com
}

Received: 04-21-2020

\begin{abstract}
A series of five new fluoro-substituted aroylhydrazones were prepared and structurally characterized by elemental analysis, IR, UV-Vis and ${ }^{1} \mathrm{H}$ NMR spectroscopy, as well as single crystal X-ray diffraction. The compounds were evaluated for their antibacterial (Bacillus subtilis, Staphylococcus aureus, Escherichia coli, and Pseudomonas fluorescence) and antifungal (Candida albicans and Aspergillus niger) activities by MTT (3-(4,5-dimethylthiazol-2-yl)-2,5-diphenyl tetrazolium bromide) method. The biological assay indicated that the presence of the electron-withdrawing groups in the aroylhydrazones improved their antimicrobial activities.
\end{abstract}

Keywords: Aroylhydrazone; antimicrobial activity; organic synthesis; single crystal X-ray diffraction

\section{Introduction}

Aroylhydrazones are a kind of special Schiff bases, which can be obtained by the condensation reaction of carbonyl-containing compounds with aroylhydrazines. These compounds have attracted great attention for their wide range of biological activities, such as antibacterial, ${ }^{1}$ antifungal, ${ }^{2}$ antitumor, ${ }^{3}$ anti-inflammatory, ${ }^{4}$ and cytotoxic. ${ }^{5}$ It was reported that the compounds bearing one or more halogen substituents in the aromatic rings can have improved biological activities especially for the antibacterial and antifungal activities. ${ }^{6}$ Rai and co-workers reported a series of fluoro-, chloro-, bromo-, and iodo-substituted compounds, and found that they have significant antimicrobial activities. ${ }^{7}$ Aroylhydrazones bearing $\mathrm{C}=\mathrm{N}-\mathrm{NH}$ $\mathrm{C}(\mathrm{O})$ functional group are also a kind of interesting ligands in coordination chemistry. To date, a number of copper, zinc, nickel, vanadium, and molybdenum complexes with aroylhydrazone ligands have been reported. ${ }^{8}$ As a continuation of work on the exploration of novel antimicrobial agents, ${ }^{9}$ in the present paper, a series of new fluoro-substituted aroylhydrazones were prepared and evaluated for their antimicrobial activities. The structureactivity relationship was also investigated.

\section{Experimental}

\section{1. Materials and Measurements}

2-Hydroxy-5-trifluoromethoxybenzaldehyde, 3-trifluoromethylbenzohydrazide, 4-methoxybenzohydrazide, picolinohydrazide, 2-chlorobenzohydrazide, 3-nitrobenzohydrazide with AR grade were purchased from Sigma-Aldrich Co. Ltd, and used as received. Elemental analyses were performed on a Perkin-Elmer 240C elemental analyzer. The IR spectra were recorded on a Jasco FT/IR4000 spectrometer with $\mathrm{KBr}$ pellets. UV-Vis spectra were recorded on a Lambdar 35 spectrometer. ${ }^{1} \mathrm{H}$ NMR spectra were recorded on a Bruker instrument at $300 \mathrm{MHz}$. X-ray diffraction was carried out at a Bruker SMART 1000 CCD area diffractometer equipped with MoKa radiation. 


\section{2. General Method for the Synthesis of the Compounds}

Equimolar quantities (1.0 mmol each) of 2-hydroxy-5-trifluoromethoxybenzaldehyde and aroylhydrazines were dissolved in methanol $(30 \mathrm{~mL})$ and were stirred at room temperature for $30 \mathrm{~min}$ to give clear solution. $\mathrm{X}$-ray quality single crystals were formed by slow evaporation of the solution in air for a few days.

\section{$N^{\prime}$-(2-Hydroxy-5-trifluoromethoxybenzylidene)-3-trif-} luoromethylbenzohydrazide (1)

Colorless crystals. Yield: 0.26 g (67\%). M.p. 189.5$190.8^{\circ} \mathrm{C}$. Anal. calcd. for $\mathrm{C}_{16} \mathrm{H}_{10} \mathrm{~F}_{6} \mathrm{~N}_{2} \mathrm{O}_{3}$ : C, 48.99; $\mathrm{H}, 2.57$; $\mathrm{N}, 7.14$; found $\mathrm{C}, 48.78 ; \mathrm{H}, 2.70 ; \mathrm{N}, 7.23 \%$. Characteristic IR data $\left(\mathrm{cm}^{-1}\right)$ : $3445(\mathrm{w}), 3221(\mathrm{w}), 1651(\mathrm{~s}), 1612(\mathrm{~m})$. UV-Vis data in methanol $(\lambda, \varepsilon): 230 \mathrm{~nm}, 1.75 \times 10^{4} \mathrm{~L} \mathrm{~mol}^{-1} \mathrm{~cm}^{-1}$; $285 \mathrm{~nm}, 1.93 \times 10^{4} \mathrm{~L} \mathrm{~mol}^{-1} \mathrm{~cm}^{-1} ; 294 \mathrm{~nm}, 1.88 \times 10^{4} \mathrm{~L}$ $\mathrm{mol}^{-1} \mathrm{~cm}^{-1} ; 330 \mathrm{~nm}, 1.70 \times 10^{4} \mathrm{~L} \mathrm{~mol}^{-1} \mathrm{~cm}^{-1}$. ${ }^{1} \mathrm{H} \mathrm{NMR}(300$ MHz, DMSO- $\left.d_{6}\right): \delta: 12.11(\mathrm{~s}, 1 \mathrm{H}, \mathrm{OH}), 11.26(\mathrm{~s}, 1 \mathrm{H}, \mathrm{NH})$, $8.63(\mathrm{~s}, 1 \mathrm{H}, \mathrm{CH}=\mathrm{N}), 8.16(\mathrm{dd}, 1 \mathrm{H}, \mathrm{ArH}), 8.07(\mathrm{~d}, 1 \mathrm{H}$, $\operatorname{ArH}), 7.95$ (d, 1H, ArH), 7.62 (s, 1H, ArH), $7.36(\mathrm{t}, 1 \mathrm{H}$, ArH), 7.03-7.01 (m, 2H, ArH).

\section{$N^{\prime}$-(2-Hydroxy-5-trifluoromethoxybenzylidene)-4-} methoxybenzohydrazide (2)

Colorless crystals. Yield: $0.27 \mathrm{~g}(75 \%)$. M.p. 172.3$173.5^{\circ} \mathrm{C}$. Anal. calcd. for $\mathrm{C}_{16} \mathrm{H}_{13} \mathrm{~F}_{3} \mathrm{~N}_{2} \mathrm{O}_{4}$ : C, 54.24; $\mathrm{H}, 3.70$; $\mathrm{N}, 7.91$; found $\mathrm{C}, 54.35 ; \mathrm{H}, 3.81 ; \mathrm{N}, 7.76 \%$. Characteristic IR data $\left(\mathrm{cm}^{-1}\right)$ : $3431(\mathrm{w}), 3259(\mathrm{w}), 1646(\mathrm{~s}), 1610(\mathrm{~m})$. UV-Vis data in methanol $(\lambda, \varepsilon): 215 \mathrm{~nm}, 1.87 \times 10^{4} \mathrm{~L} \mathrm{~mol}^{-}$ ${ }^{1} \mathrm{~cm}^{-1} ; 285 \mathrm{~nm}, 1.97 \times 10^{4} \mathrm{~L} \mathrm{~mol}^{-1} \mathrm{~cm}^{-1} ; 297 \mathrm{~nm}, 2.12 \times 10^{4}$ $\mathrm{L} \mathrm{mol}^{-1} \mathrm{~cm}^{-1} ; 330 \mathrm{~nm}, 1.72 \times 10^{4} \mathrm{~L} \mathrm{~mol}^{-1} \mathrm{~cm}^{-1}$. ${ }^{1} \mathrm{H}$ NMR $\left(300 \mathrm{MHz}, \mathrm{DMSO}-d_{6}\right): \delta: 12.08(\mathrm{~s}, 1 \mathrm{H}, \mathrm{OH}), 11.39(\mathrm{~s}, 1 \mathrm{H}$, $\mathrm{NH}), 8.65(\mathrm{~s}, 1 \mathrm{H}, \mathrm{CH}=\mathrm{N}), 7.96(\mathrm{~d}, 2 \mathrm{H}, \operatorname{ArH}), 7.62(\mathrm{~s}, 1 \mathrm{H}$, ArH), 7.31 (dd, 1H, ArH), 7.10-7.01 (m, 3H, ArH), 3.85 (s, $3 \mathrm{H}, \mathrm{CH}_{3}$ ).

\section{$N^{\prime}$-(2-Hydroxy-5-trifluoromethoxybenzylidene)picol- inohydrazide (3)}

Colorless crystals. Yield: 0.20 g (63\%). M.p. 134.0$135.5^{\circ} \mathrm{C}$. Anal. calcd. for $\mathrm{C}_{14} \mathrm{H}_{10} \mathrm{~F}_{3} \mathrm{~N}_{3} \mathrm{O}_{3}$ : C, 51.70; $\mathrm{H}, 3.10$; $\mathrm{N}, 12.92$; found $\mathrm{C}, 51.85 ; \mathrm{H}, 3.16 ; \mathrm{N}, 12.83 \%$. Characteristic IR data $\left(\mathrm{cm}^{-1}\right)$ : $3423(\mathrm{w}), 3277(\mathrm{w}), 1670(\mathrm{~s}), 1615(\mathrm{~m})$. UVVis data in methanol $(\lambda, \varepsilon): 213 \mathrm{~nm}, 2.03 \times 10^{4} \mathrm{~L} \mathrm{~mol}^{-1} \mathrm{~cm}^{-1}$; $288 \mathrm{~nm}, 1.94 \times 10^{4} \mathrm{~L} \mathrm{~mol}^{-1} \mathrm{~cm}^{-1} ; 297 \mathrm{~nm}, 1.91 \times 10^{4} \mathrm{~L}$ $\mathrm{mol}^{-1} \mathrm{~cm}^{-1} ; 333 \mathrm{~nm}, 1.87 \times 10^{4} \mathrm{~L} \mathrm{~mol}^{-1} \mathrm{~cm}^{-1} .{ }^{1} \mathrm{H}$ NMR $\left(300 \mathrm{MHz}, \mathrm{DMSO}-d_{6}\right): \delta: 12.58(\mathrm{~s}, 1 \mathrm{H}, \mathrm{OH}), 11.38(\mathrm{~s}, 1 \mathrm{H}$, $\mathrm{NH}), 8.86(\mathrm{~d}, 1 \mathrm{H}, \mathrm{PyH}), 8.75(\mathrm{~s}, 1 \mathrm{H}, \mathrm{CH}=\mathrm{N}), 8.16(\mathrm{~d}, 1 \mathrm{H}$, $\mathrm{PyH}), 8.06(\mathrm{t}, 1 \mathrm{H}, \mathrm{PyH}), 7.70(\mathrm{t}, 1 \mathrm{H}, \mathrm{PyH}), 7.57(\mathrm{~s}, 1 \mathrm{H}$, ArH), 7.05 (m, 2H, ArH).

\section{2-Chloro- $N^{\prime}$-(2-hydroxy-5-trifluoromethoxyben- zylidene)benzohydrazide (4)}

Colorless crystals. Yield: 0.29 g (81\%). M.p. 211.2$212.8^{\circ} \mathrm{C}$. Anal. calcd. for $\mathrm{C}_{15} \mathrm{H}_{10} \mathrm{ClF}_{3} \mathrm{~N}_{2} \mathrm{O}_{3}: \mathrm{C}, 50.23 ; \mathrm{H}, 2.81$; $\mathrm{N}, 7.81$; found $\mathrm{C}, 50.37 ; \mathrm{H}, 2.93 ; \mathrm{N}, 7.76 \%$. Characteristic IR data $\left(\mathrm{cm}^{-1}\right)$ : $3432(\mathrm{w}), 3215(\mathrm{w}), 1645(\mathrm{~s}), 1612(\mathrm{~m})$. UV-Vis data in methanol $(\lambda, \varepsilon): 233 \mathrm{~nm}, 1.79 \times 10^{4} \mathrm{~L} \mathrm{~mol}^{-1} \mathrm{~cm}^{-1} ; 285$ $\mathrm{nm}, 2.11 \times 10^{4} \mathrm{~L} \mathrm{~mol}^{-1} \mathrm{~cm}^{-1} ; 295 \mathrm{~nm}, 2.03 \times 10^{4} \mathrm{~L} \mathrm{~mol}^{-1}$ $\mathrm{cm}^{-1} ; 333 \mathrm{~nm}, 1.75 \times 10^{4} \mathrm{~L} \mathrm{~mol}^{-1} \mathrm{~cm}^{-1}$. ${ }^{1} \mathrm{H}$ NMR $(300$ $\left.\mathrm{MHz}, \mathrm{DMSO}-d_{6}\right): \delta: 12.26(\mathrm{~s}, 1 \mathrm{H}, \mathrm{OH}), 11.23(\mathrm{~s}, 1 \mathrm{H}, \mathrm{NH})$, $8.70(\mathrm{~s}, 1 \mathrm{H}, \mathrm{CH}=\mathrm{N}), 8.01(\mathrm{~d}, 1 \mathrm{H}, \mathrm{ArH}), 7.94(\mathrm{~d}, 1 \mathrm{H}, \mathrm{ArH})$, 7.72-7.58 (dt, 3H, ArH), 7.31 (t, 1H, ArH), $7.06(\mathrm{~d}, 1 \mathrm{H}$, ArH).

$N^{\prime}$-(2-Hydroxy-5-trifluoromethoxybenzylidene)-3-nitrobenzohydrazide (5)

Yellow crystals. Yield: $0.26 \mathrm{~g}(70 \%)$. M.p. 238.5-240.0 ${ }^{\circ} \mathrm{C}$. Anal. calcd. for $\mathrm{C}_{15} \mathrm{H}_{10} \mathrm{~F}_{3} \mathrm{~N}_{3} \mathrm{O}_{5}: \mathrm{C}, 48.79 ; \mathrm{H}, 2.73 ; \mathrm{N}$, 11.38; found $\mathrm{C}, 48.72 ; \mathrm{H}, 2.82 ; \mathrm{N}, 11.45 \%$. Characteristic IR data $\left(\mathrm{cm}^{-1}\right)$ : $3437(\mathrm{w}), 3215(\mathrm{w}), 1645(\mathrm{~s}), 1613(\mathrm{~m})$, 1530 (s), 1354 (s). UV-Vis data in methanol $(\lambda, \varepsilon): 215 \mathrm{~nm}$, $2.23 \times 10^{4} \mathrm{~L} \mathrm{~mol}^{-1} \mathrm{~cm}^{-1} ; 283 \mathrm{~nm}, 1.63 \times 10^{4} \mathrm{~L} \mathrm{~mol}^{-1} \mathrm{~cm}^{-1}$; $330 \mathrm{~nm}, 1.51 \times 10^{4} \mathrm{~L} \mathrm{~mol}^{-1} \mathrm{~cm}^{-1} ; 390 \mathrm{~nm}, 4.33 \times 10^{3} \mathrm{~L}$ $\mathrm{mol}^{-1} \mathrm{~cm}^{-1} .{ }^{1} \mathrm{H}$ NMR $\left(300 \mathrm{MHz}, \mathrm{DMSO}-d_{6}\right): \delta: 12.47(\mathrm{~s}$, $1 \mathrm{H}, \mathrm{OH}), 11.19(\mathrm{~s}, 1 \mathrm{H}, \mathrm{NH}), 8.81(\mathrm{~s}, 1 \mathrm{H}, \mathrm{ArH}), 8.75(\mathrm{~s}, 1 \mathrm{H}$, $\mathrm{CH}=\mathrm{N}), 8.50(\mathrm{dd}, 1 \mathrm{H}, \mathrm{ArH}), 8.39(\mathrm{~d}, 1 \mathrm{H}, \mathrm{ArH}), 7.88(\mathrm{t}$, $1 \mathrm{H}, \mathrm{ArH}), 7.68$ (s, 1H, ArH), 7.05 (m, 2H, ArH).

\section{3. Antimicrobial Assay}

The antibacterial activities of the compounds were tested against B. subtilis, S. aureus, E. coli, and P. fluorescence using $\mathrm{MH}$ (Mueller-Hinton) medium. The antifungal activities of the compounds were tested against $C$. albicans and $A$. niger using RPMI-1640 medium. The MIC values of the tested compounds were determined by a colorimetric method using the dye MTT. ${ }^{10}$ A stock solution of the aroylhydrazone compound $(150 \mu \mathrm{M})$ in DMSO was prepared and graded quantities $(75 \mu \mathrm{M}, 37.5 \mu \mathrm{M}, 18.8 \mu \mathrm{M}, 9.4 \mu \mathrm{M}, 4.7$ $\mu \mathrm{M}, 2.3 \mu \mathrm{M}, 1.2 \mu \mathrm{M}, 0.59 \mu \mathrm{M})$ of the tested compounds were incorporated in specified quantity of the corresponding sterilized liquid medium. A specified quantity of the medium containing the compound was poured into microtitration plates. Suspension of the microorganism was prepared to contain approximately $10^{5} \mathrm{cfu} / \mathrm{mL}$ and applied to microtitration plates with serially diluted compounds in DMSO to be tested and incubated at $37^{\circ} \mathrm{C}$ for $24 \mathrm{~h}$ and $48 \mathrm{~h}$ for bacteria and fungi, respectively. Then the MIC values were visually determined on each of the microtitration plates, 50 $\mu \mathrm{L}$ of PBS (phosphate buffered saline $0.01 \mathrm{M}, \mathrm{pH}=7.4$ ) containing $2 \mathrm{mg}$ of $\mathrm{MTT} / \mathrm{mL}$ was added to each well. Incubation was continued at room temperature for $4-5 \mathrm{~h}$. The content of each well was removed, and $100 \mu \mathrm{L}$ of isopropanol containing $5 \% 1 \mathrm{M} \mathrm{HCl}$ was added to extract the dye. After 12 $h$ of incubation at room temperature, the optical density was measured with a microplate reader at $550 \mathrm{~nm}$.

\section{4. Crystal Structure Determination}

Diffraction intensities for the compounds were collected at 298(2) K using a Bruker SMART 1000 CCD 
Table 1. Crystallographic and experimental data for the compounds 1-5

\begin{tabular}{|c|c|c|c|c|c|}
\hline Compound & 1 & 2 & 3 & 4 & 5 \\
\hline Formula & $\mathrm{C}_{16} \mathrm{H}_{10} \mathrm{~F}_{6} \mathrm{~N}_{2} \mathrm{O}_{3}$ & $\mathrm{C}_{16} \mathrm{H}_{13} \mathrm{~F}_{3} \mathrm{~N}_{2} \mathrm{O}_{4}$ & $\mathrm{C}_{14} \mathrm{H}_{10} \mathrm{~F}_{3} \mathrm{~N}_{3} \mathrm{O}_{3}$ & $\mathrm{C}_{15} \mathrm{H}_{10} \mathrm{ClF}_{3} \mathrm{~N}_{2} \mathrm{O}_{3}$ & $\mathrm{C}_{15} \mathrm{H}_{10} \mathrm{~F}_{3} \mathrm{~N}_{3} \mathrm{O}_{5}$ \\
\hline$M r$ & 392.3 & 354.3 & 325.2 & 363.2 & 369.3 \\
\hline Crystal system & Monoclinic & Monoclinic & Orthorhombic & Monoclinic & Monoclinic \\
\hline Space group & $P 2_{1} / c$ & $P 2_{1} / c$ & $\mathrm{Pbca}$ & $P 2_{1} / c$ & $P 2_{1} / c$ \\
\hline$a(\AA)$ & $12.0732(9)$ & $18.9700(11)$ & $7.4144(8)$ & $11.4106(5)$ & $11.6290(7)$ \\
\hline$b(\AA)$ & $14.9373(10)$ & $8.3470(10)$ & $11.2352(10)$ & $14.9261(7)$ & $14.7428(8)$ \\
\hline$c(\AA)$ & $8.8606(7)$ & $10.1475(11)$ & $34.8550(13)$ & $8.9011(4)$ & $8.8921(5)$ \\
\hline$\beta\left(^{\circ}\right)$ & $95.045(2)$ & $94.342(2)$ & & $94.5490(10)$ & $96.192(1)$ \\
\hline$V\left(\AA^{3}\right)$ & $1591.7(2)$ & $1602.2(3)$ & $2903.5(4)$ & $1511.22(12)$ & $1515.60(15)$ \\
\hline$Z$ & 4 & 4 & 8 & 4 & 4 \\
\hline$D_{c}\left(\mathrm{~g} \mathrm{~cm}^{-3}\right)$ & 1.637 & 1.469 & 1.488 & 1.577 & 1.618 \\
\hline$\mu(\mathrm{Mo}-\mathrm{K} \alpha)\left(\mathrm{mm}^{-1}\right)$ & 0.160 & 0.129 & 0.132 & 0.304 & 0.146 \\
\hline$F(000)$ & 792 & 728 & 1328 & 728 & 752 \\
\hline Reflections collected & 7941 & 7607 & 11701 & 14025 & 14255 \\
\hline Unique reflections & 2953 & 2931 & 2650 & 2770 & 2813 \\
\hline Observed reflections $(I \geq 2 \sigma(I))$ & 2182 & 1289 & 1537 & 2300 & 1972 \\
\hline Parameters & 249 & 233 & 212 & 221 & 239 \\
\hline Restraints & 1 & 2 & 1 & 1 & 1 \\
\hline Min. and max. transmission & 0.9581 and 0.9642 & 0.9809 and 0.9835 & 0.9703 and 0.9741 & 0.9389 and 0.9502 & 0.9588 and 0.9671 \\
\hline Goodness-of-fit on $F^{2}$ & 1.032 & 1.028 & 0.965 & 1.042 & 1.030 \\
\hline$R_{1}, w R_{2}[I \geq 2 \sigma(I)]^{a}$ & $0.0442,0.1060$ & $0.0880,0.2385$ & $0.0813,0.1858$ & $0.0395,0.0983$ & $0.0426,0.0955$ \\
\hline$R_{1}, w R_{2}$ (all data) ${ }^{a}$ & $0.0656,0.1212$ & $0.1716,0.3191$ & $0.1278,0.2241$ & $0.0496,0.1073$ & $0.0704,0.1088$ \\
\hline Large diff. peak and hole $\left(\mathrm{e}^{-3}\right)$ & 0.296 and -0.234 & 0.564 and -0.268 & 0.270 and -0.223 & 0.235 and -0.313 & 0.203 and -0.197 \\
\hline
\end{tabular}

${ }^{a} R_{1}=\Sigma|| F_{\mathrm{o}}|-| F_{\mathrm{c}}|| \Sigma\left|F_{\mathrm{o}}\right|, w R_{2}=\left[\Sigma w\left(F_{\mathrm{o}}{ }^{2}-F_{\mathrm{c}}{ }^{2}\right)^{2} / \Sigma w\left(F_{\mathrm{o}}{ }^{2}\right)^{1 / 2}\right.$.

area-detector diffractometer with Mo Ka radiation $(\lambda=$ $0.71073 \AA)$. The collected data were reduced with the SAINT program, ${ }^{11}$ and multi-scan absorption correction was performed using the SADABS program. ${ }^{12}$ The structures were solved by direct methods. The compounds were refined against $F^{2}$ by full-matrix least-squares method using the SHELXTL package. ${ }^{13}$ All of the non-hydrogen atoms were refined anisotropically. The amino $\mathrm{H}$ atoms in the compounds were located from difference Fourier maps and refined isotropically, with $\mathrm{N}-\mathrm{H}$ distances restrained to<smiles>[R]C(=O)N/N=C/c1cc(OC(F)(F)F)ccc1O</smiles>

5

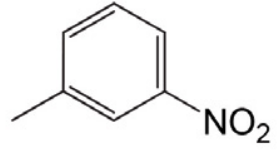

Scheme 1. Synthesis of the compounds 1-5.

Wang et al.: Synthesis, Characterization and Crystal Structures of ... 
0.90(1) A. The remaining hydrogen atoms were placed in calculated positions and constrained to ride on their parent atoms. The crystallographic data for the compounds are summarized in Table 1.

\section{Results and Discussion}

\section{1. Synthesis and General Characterization}

The aroylhydrazones were prepared by the condensation of equimolar quantities of 2-hydroxy-5trifluoromethoxybenzaldehyde with various aroylhydrazines in methanol (Scheme 1). The compounds have been characterized by elemental analysis, IR, UV-Vis and ${ }^{1} \mathrm{H}$ NMR spectra. Structures of the compounds were further confirmed by single crystal X-ray determination. The compounds were crystallized as well-shaped single crystals, which are soluble in methanol, ethanol, acetonitrile, chloroform, DMF and DMSO, but insoluble in pure water.

\section{2. IR and Electronic Spectra}

The characteristic intense bands in the range 1645$1670 \mathrm{~cm}^{-1}$ are generated by the $v(\mathrm{C}=\mathrm{O})$ vibrations, whereas the bands in the range $1610-1615 \mathrm{~cm}^{-1}$ are assigned to the $v(\mathrm{C}=\mathrm{N})$ vibrations. ${ }^{14}$ In the spectra of the compounds, there are broad absorptions in the range $3420-3450 \mathrm{~cm}^{-1}$, which can be attributed to the hydrogen-bonded phenol groups. The sharp bands in the range $3215-3277 \mathrm{~cm}^{-1}$ are assigned to the $v(\mathrm{~N}-\mathrm{H})$ vibrations. The bands indicative of the $v_{a s}\left(\mathrm{NO}_{2}\right)$ and $v_{s}\left(\mathrm{NO}_{2}\right)$ vibrations are observed at 1530 and $1354 \mathrm{~cm}^{-1}$ for $5 .{ }^{13}$ In the electronic spectra of the compounds, there are four sets of bands in the UV regions. The first at $283-288 \mathrm{~nm}$ may be assigned to $\pi-\pi^{\star}$ transitions in the aromatic and intra-ligand $\pi-\pi^{\star}$ transitions. ${ }^{15}$ The second set at $330-390 \mathrm{~nm}$ may be assigned to $n-\pi^{\star}$ transitions of the azomethine and carbonyl groups. ${ }^{16}$ The $\mathrm{C}, \mathrm{H}, \mathrm{N}$ analyses were in accordance with the chemical formulae proposed by the single crystal X-ray analysis.

\section{3. ${ }^{1} \mathrm{H}$ NMR Spectra}

The ${ }^{1} \mathrm{H}$ NMR data of the compounds show no signal of the amino group $\left(\mathrm{NH}_{2}\right)$ characteristic to the starting material (hydrazide). The spectra show singlet at $12-13$ and 11-12 ppm ranges, which may be assigned to the hydroxyl proton $(\mathrm{OH})$ and $(\mathrm{NH})$ protons, respectively. ${ }^{17}$ The singlet at $8.6-8.8 \mathrm{ppm}$ range is assigned to the azomethine proton

Table 2. Selected bond lengths $(\AA)$ and angles $\left(^{\circ}\right)$ for the compounds 1-5

\begin{tabular}{lccccc}
\hline & $\mathbf{1}$ & $\mathbf{2}$ & $\mathbf{3}$ & $\mathbf{4}$ & $\mathbf{5}$ \\
\hline C8-N1 & $1.278(3)$ & $1.277(6)$ & $1.293(5)$ & $1.278(2)$ & $1.276(2)$ \\
N1-N2 & $1.382(2)$ & $1.362(5)$ & $1.364(5)$ & $1.377(2)$ & $1.380(2)$ \\
N2-C9 & $1.347(3)$ & $1.365(6)$ & $1.367(5)$ & $1.347(2)$ & $1.342(2)$ \\
C9-O2 & $1.227(2)$ & $1.226(5)$ & $1.230(5)$ & $1.230(2)$ & $1.227(2)$ \\
C8-N1-N2 & $116.01(17)$ & $119.1(4)$ & $120.8(3)$ & $117.04(15)$ & $117.39(16)$ \\
N1-N2-C9 & $119.56(16)$ & $116.8(4)$ & $116.3(4)$ & $118.76(14)$ & $117.96(15)$ \\
N2-C9-C10 & $115.08(17)$ & $115.4(4)$ & $114.2(4)$ & $115.61(14)$ & $115.96(16)$ \\
N2-C9-O2 & $122.98(19)$ & $121.5(4)$ & $122.4(4)$ & $122.74(16)$ & $123.06(17)$ \\
\hline
\end{tabular}

Table 3. Hydrogen bond distances $(\AA)$ and bond angles $\left({ }^{\circ}\right)$ for the compounds 1-5

\begin{tabular}{lcccc}
\hline$D-\mathrm{H} \cdots A$ & $d(D-\mathbf{H})$ & $d(\mathbf{H} \cdots A)$ & $d(D \cdots A)$ & Angle $(D-\mathbf{H} \cdots A)$ \\
\hline $\mathbf{1}$ & & & & \\
$\mathrm{N} 2-\mathrm{H} 2 \cdots \mathrm{O} 2^{\mathrm{i}}$ & $0.90(1)$ & $2.035(12)$ & $2.916(2)$ & $165(3)$ \\
$\mathrm{O} 1-\mathrm{H} 1 \cdots \mathrm{N} 1$ & 0.82 & 1.92 & $2.644(2)$ & $146(3)$ \\
$\mathbf{2}$ & & & & \\
$\mathrm{N} 2-\mathrm{H} 2 \cdots \mathrm{O} 2^{\mathrm{i}}$ & $0.90(1)$ & $2.144(16)$ & $3.021(4)$ & $165(4)$ \\
$\mathrm{O} 1-\mathrm{H} 1 \cdots \mathrm{N} 1$ & $0.85(1)$ & $1.79(3)$ & $2.554(5)$ & $149(5)$ \\
$\mathbf{3}$ & & & & \\
$\mathrm{N} 2-\mathrm{H} 2 \cdots \mathrm{O} 2^{\mathrm{ii}}$ & $0.90(1)$ & $2.60(3)$ & $3.396(5)$ & $147(4)$ \\
$\mathrm{O} 1-\mathrm{H} 1 \cdots \mathrm{N} 1$ & 1.00 & 1.62 & $2.534(4)$ & $149(4)$ \\
$\mathbf{4}$ & & & & $166(2)$ \\
$\mathrm{N} 2-\mathrm{H} 2 \cdots \mathrm{O} 2^{\mathrm{ii}}$ & $0.90(1)$ & $2.056(12)$ & $2.929(2)$ & $146(2)$ \\
$\mathrm{O} 1-\mathrm{H} 1 \cdots \mathrm{N} 1$ & 0.82 & 1.91 & $2.629(2)$ & \\
$\mathbf{5}$ & & & & $166(2)$ \\
$\mathrm{N} 2-\mathrm{H} 2 \cdots \mathrm{O} 2^{\mathrm{i}}$ & $0.90(1)$ & $2.058(12)$ & $2.937(2)$ & $145(2)$ \\
$\mathrm{O} 1-\mathrm{H} 1 \cdots \mathrm{N} 1$ & 0.82 & 1.91 & $2.622(2)$ & \\
\hline
\end{tabular}

Symmetry codes: (i) $x, 1 / 2-y,-1 / 2+z$; (ii) $1 / 2-x, 1 / 2+y, z$; (iii) $x, 3 / 2-y,-1 / 2+z$.

Wang et al.: Synthesis, Characterization and Crystal Structures of ... 


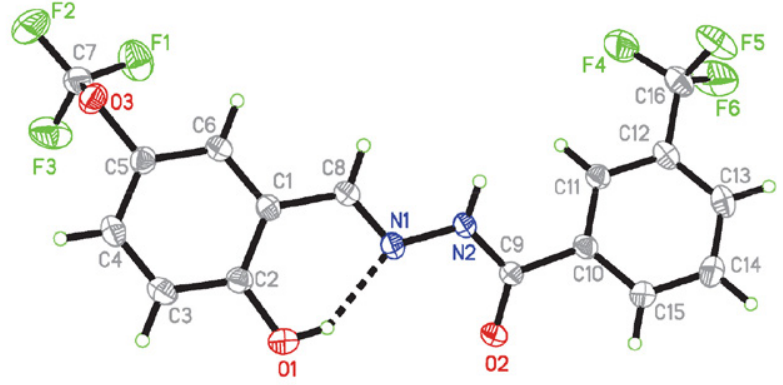

Figure 1. A perspective view of the molecular structure of $\mathbf{1}$ with the atom labeling scheme. Thermal ellipsoids are drawn at the 30\% probability level. Hydrogen bond is shown as a dashed line.

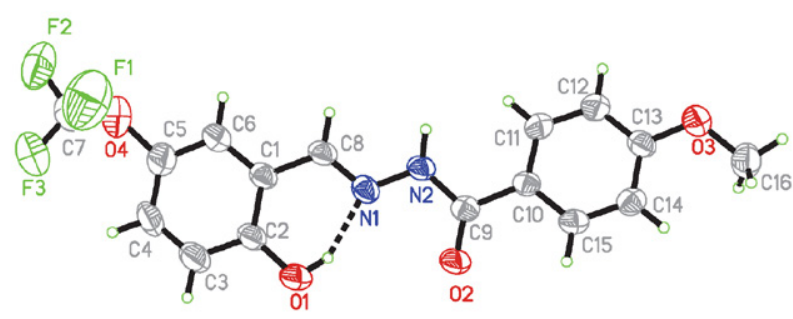

Figure 2. A perspective view of the molecular structure of 2 with the atom labeling scheme. Thermal ellipsoids are drawn at the 30\% probability level. Hydrogen bond is shown as a dashed line.

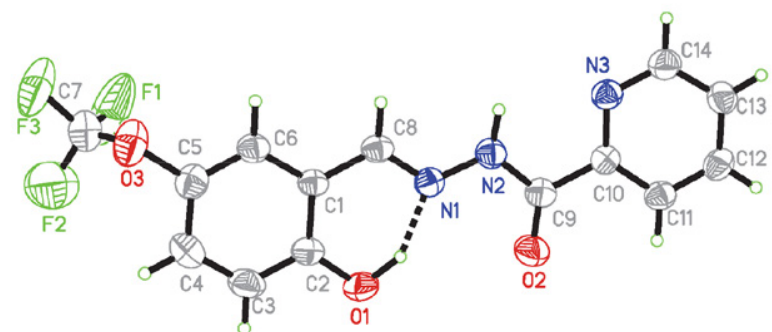

Figure 3. A perspective view of the molecular structure of $\mathbf{3}$ with the atom labeling scheme. Thermal ellipsoids are drawn at the 30\% probability level. Hydrogen bonds are shown as dashed lines.

$(\mathrm{CH}=\mathrm{N}) .{ }^{18}$ The multiplets in the $8.05-7.00 \mathrm{ppm}$ range are attributed to aromatic protons. ${ }^{19}$ The triplet at $3.85 \mathrm{ppm}$ for compound $\mathbf{2}$ is attributed to the methyl group.

\section{4. Crystal Structure Description}

The molecular structures of the compounds 1-5 are shown in Figures 1-5, respectively. Selected bond lengths and angles are listed in Table 2. All the molecules of the compounds adopt $E$ configuration with respect to the methylidene units. The distances of the methylidene bonds, ranging from 1.27 to $1.30 \AA$, confirm them as typical double bonds. The shorter distances of the $\mathrm{C}-\mathrm{N}$ bonds and the longer distances of the $\mathrm{C}=\mathrm{O}$ bonds for the $-\mathrm{C}(\mathrm{O})-\mathrm{NH}-$ units than usual, suggest the presence of conjugation effects in the molecules. All the bond lengths in the compounds are comparable to each other, and are within normal values. ${ }^{20}$ The aromatic rings of the

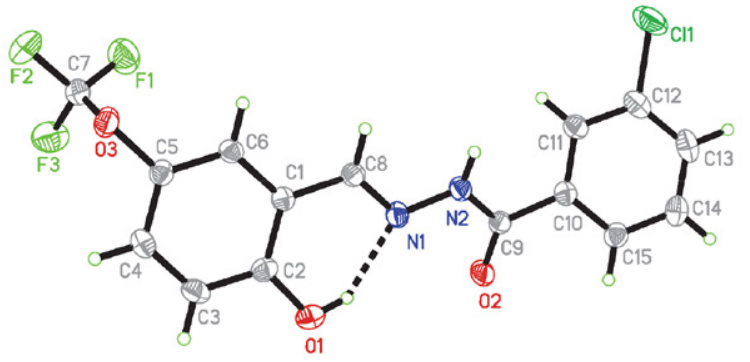

Figure 4. A perspective view of the molecular structure of 4 with the atom labeling scheme. Thermal ellipsoids are drawn at the $30 \%$ probability level. Hydrogen bond is shown as a dashed line.

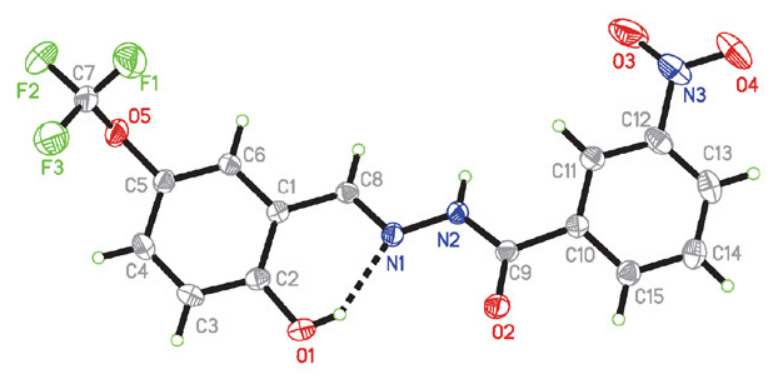

Figure 5. A perspective view of the molecular structure of $\mathbf{5}$ with the atom labeling scheme. Thermal ellipsoids are drawn at the $30 \%$ probability level. Hydrogen bond is shown as a dashed line.

compounds form dihedral angles of $10.9(2)^{\circ}(1), 14.2(4)^{\circ}$ (2), $9.7(4)^{\circ}(3), 9.6(2)^{\circ}(4)$, and $5.4(2)^{\circ}(5)$. The crystal structures of the compounds are stabilized by intermolecular hydrogen bonds (Table 3).

\section{5. Antimicrobial Activity}

The compounds were screened for antibacterial activity against two Gram positive bacterial strains ( $B$. subtilis and $S$. aureus) and two Gram negative bacterial strains (E. coli and P. fluorescence) by MTT method. The MIC (minimum inhibitory concentration) values of the compounds against four bacteria are listed in Table 4 . Kanamycin and Penicillin G were used as the standard materials. Compounds $\mathbf{1}$ and $\mathbf{4}$ showed the most effective activities against $B$. subtilis, and good activities against $S$. aureus and E. coli, while no or weak activity against $P$. fluorescence. Compounds $\mathbf{2}$ and $\mathbf{5}$ showed moderate activities against all the bacteria. Compound $\mathbf{3}$ showed weak activity agains $B$. subtilis and $E$. coli, while no activity against $E$. coli and P. fluorescence. After careful comparison we noticed that the presence of a trifluoromethyl group in $\mathbf{1}$ and a chloro group in $\mathbf{4}$ might play an important role in the antibacterial activities. In addition, the presence of an electron-withdrawing group $\left(\mathrm{NO}_{2}\right)$ in compound $\mathbf{5}$ made it more active than the compounds $\mathbf{2}$ and $\mathbf{3}$ which are bearing methoxybenzene and pyridine groups. The chloro substituents are known to be important constituents 
Table 4. The MIC values $(\mu \mathrm{M})$ of the compounds 1-5

\begin{tabular}{lcccccc}
\hline Tested material & $\begin{array}{c}\text { Bacillus } \\
\text { subtilis }\end{array}$ & $\begin{array}{c}\text { Staphylococcus } \\
\text { aureus }\end{array}$ & $\begin{array}{c}\text { Escherichia } \\
\text { coli }\end{array}$ & $\begin{array}{c}\text { Pseudomonas } \\
\text { fluorescence }\end{array}$ & $\begin{array}{c}\text { Candida } \\
\text { albicans }\end{array}$ & $\begin{array}{c}\text { Aspergillus } \\
\text { niger }\end{array}$ \\
\hline $\mathbf{1}$ & 0.62 & 9.4 & 18.7 & $>150$ & $>150$ & 75 \\
$\mathbf{2}$ & 9.4 & 37.5 & 75 & $>150$ & $>150$ & $>150$ \\
$\mathbf{3}$ & 18.7 & 37.5 & $>150$ & $>150$ & $>150$ & $>150$ \\
$\mathbf{4}$ & 0.31 & 9.4 & 18.7 & 37.5 & 37.5 & $>150$ \\
$\mathbf{5}$ & 3.13 & 18.7 & 75 & $>150$ & $>150$ & $>150$ \\
Kanamycin & 0.59 & 2.3 & 4.7 & 4.7 & $>150$ & $>150$ \\
Penicillin G & 2.3 & 4.7 & $>150$ & $>150$ & $>150$ & $>150$ \\
Ketoconazole & $>150$ & $>150$ & $>150$ & $>150$ & 4.7 & 18.8 \\
\hline
\end{tabular}

conferring the antibacterial activities. ${ }^{21}$ It is interesting that compounds $\mathbf{1}$ and $\mathbf{4}$ have similar activities against $B$. subtilis as Kanamycin and Penicillin G. The results indicate that the electron-withdrawing groups on the aromatic rings may be important for the design of novel antibacterial materials.

The antifungal activities of the compounds were also evaluated against two fungal strains (C. albicans and $A$. niger) by MTT method. Ketoconazole was used as the reference mateiral. As a result, compound $\mathbf{4}$ has weak activity against $C$. albicans, and compound $\mathbf{1}$ has weak activity against $A$. niger.

\section{Conclusions}

In the present paper a series of five new fluoro-substituted aroylhydrazones were prepared and structurally characterized. The antimicrobial activities against the bacteria B. subtilis, S. aureus, E. coli, and P. fluorescence, and the fungi $C$. albicans and $A$. niger were evaluated by MTT methods. Among the compounds, $N$ '-(2-hydroxy-5-trifluoromethoxybenzylidene)-3-trifluoromethylbenzohydrazide and 2-chloro- $N$ '-(2-hydroxy-5-trifluoromethoxybenzylidene)benzohydrazide showed to be the most effective antimicrobial agents against $B$. subtilis. The electron-withdrawing groups, such as nitro, chloro, and fluoro, are important substituents for the design of novel effective antibacterial agents. The compounds presented here could be useful as a template for future development through modification to explore more effective antimicrobial materials.

\section{Supplementary material}

CCDC-1998070 for 1, 1998075 for 2, 1998076 for 3, 1998077 for 4, 1998079 for $\mathbf{5}$ contain the supplementary crystallographic data for this paper. These data can be obtained free of charge at http://www.ccdc.cam.ac.uk/ const/retrieving.html or from the Cambridge Crystallographic Data Centre (CCDC), 12 Union Road, Cambridge CB2 1EZ, UK; fax: +44(0)1223-336033 or e-mail: deposit@ ccdc.cam.ac.uk.

\section{References}

1. (a) M. V. Angelusiu, S. F. Barbuceanu, C. Draghici, G. L. Almajan, Eur. J. Med. Chem. 2010, 45, 2055-2062;

DOI:10.1016/j.ejmech.2010.01.033

(b) O. O. Ajani, C. A. Obafemi, O. C. Nwinyi, D. A. Akinpelu, Bioorg. Med. Chem. 2010, 18, 214-221.

DOI:10.1016/j.bmc.2009.10.064

2. G. Visbal, G. San-Blas, A. Maldonado, A. Alvarez-Aular, M. V. Capparelli, J. Murgich, Steroids 2011, 76, 1069-1081.

DOI:10.1016/j.steroids.2011.04.012

3. (a) Y. H. Zhang, L. Zhang, L. Liu, J. X. Guo, D. L. Wu, G. C. Xu, X. H. Wang, D. Z. Jia, Inorg. Chim. Acta 2010, 363, 289-293; DOI:10.1016/j.ica.2009.08.017

(b) T. Horiuchi, J. Chiba, K. Uoto, T. Soga, Bioorg. Med. Chem. Lett. 2009, 19, 305-308.

DOI:10.1016/j.bmcl.2008.11.090

4. (a) M. A. A. El-Sayed, N. I. Abdel-Aziz, A. A. M. Abdel-Aziz, A. S. El-Azab, Y. A. Asiri, K. E. H. ElTahir, Bioorg. Med. Chem. 2011, 19, 3416-3424; DOI:10.1016/j.bmc.2011.04.027

(b) S. M. Sondhi, M. Dinodia, A. Kumar, Bioorg. Med. Chem. 2006, 14, 4657-4663. DOI:10.1016/j.bmc.2006.02.014

5. (a) P. Krishnamoorthy, P. Sathyadevi, A. H. Cowley, R. R. Butorac, N. Dharmaraj, Eur. J. Med. Chem. 2011, 46, 33763387; DOI:10.1016/j.ejmech.2011.05.001

(b) P. G. Avaji, C. H. V. Kumar, S. A. Patil, K. N. Shivananda, C. Nagaraju, Eur. J. Med. Chem. 2009, 44, 3552-3559.

DOI:10.1016/j.ejmech.2009.03.032

6. (a) L. C. Felton, J. H. Brewer, Science 1947, 105, 409-410; DOI:10.1126/science.105.2729.409

(b) M. Gopalakrishnan, J. Thanusu, V. Kanagarajan, R. Govindaraju, J. Enzyme Inhib. Med. Chem. 2009, 24, 52-58; DOI:10.1080/14756360801906632

(c) L. Shi, H.-M. Ge, S.-H. Tan, H.-Q. Li, Y.-C. Song, H.-L. Zhu, R.-X. Tan, Eur. J. Med. Chem. 2007, 42, 558-564.

DOI:10.1016/j.ejmech.2006.11.010

7. (a) N. P. Rai, V. K. Narayanaswamy, T. Govender, B. K. Manuprasad, S. Shashikanth, P. N. Arunachalam, Eur. J. Med. Chem. 2010, 45, 2677-2682;

DOI:10.1016/j.ejmech.2010.02.021

(b) N. P. Rai, V. K. Narayanaswamy, S. Shashikanth, P. N. Arunachalam, Eur. J. Med. Chem. 2009, 44, 4522-4527.

8. (a) E.-C. Liu, W. Li, X.-S. Cheng, Acta Chim. Slov. 2019, 66, 971-977; 
(b) H.-Y. Qian, Acta Chim. Slov. 2019, 66, 995-1001; DOI:10.4149/neo_2019_190112N36

(c) Y. Li, L. Xu, M. Duan, J. Wu, Y. Wang, K. Dong, M. Han, Z. You, Inorg. Chem. Commun. 2019, 105, 212-216; DOI:10.1016/j.inoche.2019.05.011

(d) X.-Q. Luo, Y.-J. Han, L.-W. Han, Acta Chim. Slov. 2020, 67, 853-859; DOI:10.17344/acsi.2020.5819

(e) Z. You, H. Yu, B. Zheng, C. Zhang, C. Lv, K. Li, L. Pan, Inorg. Chim. Acta 2018, 469, 44-50;

DOI:10.1016/j.ica.2017.09.011

(f) Y.-L. Sang, X.-S. Lin, W.-D. Sun, Acta Chim. Slov. 2020, 67, 581-585; DOI:10.17344/acsi.2019.5595

(g) H. Zhao, X.-P. Tan, Q.-A. Peng, C.-Z. Shi, Y.-F. Zhao, Y. Cui, Acta Chim. Slov. 2020, 67, 638-643.

DOI:10.17344/acsi.2019.5644

9. (a) R.-H. Hui, P. Zhou, Z.-L. You, Indian J. Chem. A 2009, 48, 1102-1106; DOI:10.1111/j.1755-3768.1970.tb06590.x

(b) Z.-L. You, H.-L. Zhu, Z. Anorg. Allg. Chem. 2006, 632, 140-146; DOI:10.1002/zaac.200500308

(c) Z.-L. You, Q.-Z. Jiao, Synth. React. Inorg. Met.-Org. NanoMet. Chem. 2006, 36, 713-717.

DOI:10.1080/15533170601028165

10. J. Meletiadis, J. F. Meis, J. W. Mouton, J. P. Donnelly, P. E. Verweij, J. Clin. Microbiol. 2000, 38, 2949-2954.

DOI:10.1128/JCM.38.8.2949-2954.2000

11. Bruker, SMART (Version 5.625) and SAINT (Version 6.01). Bruker AXS Inc., Madison, Wisconsin, USA, 2007.

12. G. M. Sheldrick. SADABS. Program for Empirical Absorption Correction of Area Detector, University of Göttingen, Germany, 1996.
13. G. M. Sheldrick. SHELXTL V5.1 Software Reference Manual, Bruker AXS, Inc., Madison, Wisconsin, USA, 1997.

14. M. Zhang, D.-M. Xian, H.-H. Li, J.-C. Zhang, Z.-L. You, Aust. J. Chem. 2012, 65, 343-350. DOI:10.1071/CH11424

15. M. F. R. Fouda, M. M. Abd-Elzaher, M. M. Shakdofa, F. A. El-Saied, M. I. Ayad, A. S. El-Tabl, J. Coord. Chem. 2008, 61, 1983-1996. DOI:10.1080/00958970701795714

16. R. Gup, B. Kirkan, Spectrochim. Acta A 2005, 62, 1188-1195. DOI:10.1016/j.saa.2005.04.015

17. Ü. Ö. Özmen, G. Olgun, Spectrochim. Acta A 2008, 70, 641645. DOI:10.1016/j.saa.2007.08.012

18. M. R. Maurya, S. Khurana, C. Schulzke, D. Rehder, Eur. J. Inorg. Chem. 2001, 3, 779-788. DOI:10.1002/10990682(200103)2001:3<779::AID-EJIC779>3.0.CO;2-\#

19. P. N. Remya, C. H. Suresh, M. L. P. Reddy, Polyhedron 2007, 26, 5016-5022. DOI:10.1016/j.poly.2007.07.020

20. (a) S. N. Podyachev, I. A. Litvinov, R. R. Shagidullin, B. I. Buzykin, I. Bauer, D. V. Osyanina, L. V. Avvakumova, S. N. Sudakova, W. D. Habicher, A. I. Konovalov, Spectrochim. Acta Part A 2007, 66, 250-261; (b) S. M. S. V. Wardell, M. V. N. de Souza, J. L. Wardell, J. N. Low, C. Glidewell, Acta Crystallogr. 2005, C61, o683-0689; (c) X.-L. Wang, Z.-L. You, C. Wang, J. Chem. Crystallogr. 2011, 41, 621-624. DOI:10.1016/j.saa.2006.02.049

21. Ö. Ö. Güven, T. Erdoğan, H. Göker, S. Yıldız, Bioorg. Med. Chem. 2007, 17,2233-2236. DOI:10.1016/j.bmcl.2007.01.061

\section{Povzetek}

Opisujemo pripravo in strukturno karakterizacijo (elementna analiza, IR, UV-Vis in ${ }^{1} \mathrm{H}$ NMR spektroskopija ter rentgenska difrakcijska analiza monokristalov) petih novih fluorosubstituiranih aroilhidrazonov. Za vse spojine smo s pomočjo metode MTT (3-(4,5-dimetiltiazol-2-il)-2,5-difenil tetrazolijev bromid) določili tudi njihovo antibakterijsko delovanje (Bacillus subtilis, Staphylococcus aureus, Escherichia coli in Pseudomonas fluorescence) ter učinkovanje proti glivam (Candida albicans in Aspergillus niger), ki so pokazala, da prisotnost elektronakceptorskih skupin v aroilhidrazonih izboljša njihove antimikrobne aktivnosti.

Except when otherwise noted, articles in this journal are published under the terms and conditions of the Creative Commons Attribution 4.0 International License 